Discussion Paper No. 15-031

Does Foreign Direct Investment Synchronise Business Cycles? Results from a Panel Approach

Claudia Fries and Marcus Kappler

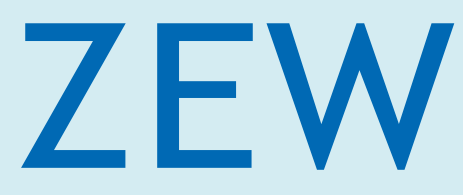

Zentrum für Europäische Wirtschaftsforschung $\mathrm{GmbH}$ Centre for European Economic Research 
Discussion Paper No. 15-031

\title{
Does Foreign Direct Investment Synchronise Business Cycles? Results from a Panel Approach
}

\author{
Claudia Fries and Marcus Kappler
}

Download this ZEW Discussion Paper from our ftp server:

http://ftp.zew.de/pub/zew-docs/dp/dp15031.pdf

Die Discussion Papers dienen einer möglichst schnellen Verbreitung von neueren Forschungsarbeiten des ZEW. Die Beiträge liegen in alleiniger Verantwortung der Autoren und stellen nicht notwendigerweise die Meinung des ZEW dar.

Discussion Papers are intended to make results of ZEW research promptly available to other economists in order to encourage discussion and suggestions for revisions. The authors are solely responsible for the contents which do not necessarily represent the opinion of the ZEW. 


\title{
Does Foreign Direct Investment Synchronise Business Cycles? Results from a Panel Approach*
}

\author{
Claudia Fries** Marcus Kappler
}

April 2015

\begin{abstract}
This study readdresses the determinants of business cycle synchronisation. We test, on the one hand, whether FDI promoting policies may have consequences for the business cycle comovement between countries, and on the other hand, whether more plausible identification strategies change previous results. Our results suggest that linkages through foreign direct investment contribute in most cases positively to the synchronisation between country pairs. In contrast, the beneficial effects of trade integration for the similarity of business cycles are less robust and thus less important for the transmission of idiosyncratic shocks between countries than previously thought. Finally, we find that larger differences in the sector structure between two economies result in a bigger gap between their business cycles.
\end{abstract}

JEL classification: F21, F41, F44, F49

Keywords: Business Cycle Synchronisation, FDI, Trade, Sectoral Differences, Panel

*We thank the participants in seminars at the ZEW Mannheim and the University of Augsburg, the WWWforEurope Area 4 Workshop on Governance Structures and Institutions at the European Level in Mannheim, the 3rd IWH/INFER Workshop on Applied Economics and Economic Policy in Halle (Saale), the EBES 2012 Conference in Warsaw, the Spring Meeting of Young Economists 2013 in Aarhus and the GPEN-CGR Annual Conference 2013 in London for helpful comments and suggestions. Marta Giagheddu provided excellent research assistance. The research leading to these results has received funding from the European Commission's Seventh Framework Programme FP7/2007-2013 under grant agreement no. 290647. Any errors are our own.

${ }^{* *}$ Corresponding Author: Centre for European Economic Research (ZEW), P.O. Box 103443, D-68034 Mannheim, Germany, Phone: +49/621/1235-336, Fax: +49/621/1235-223, E-mail: claudia.fries@zew.de 


\section{Introduction}

In this study, we identify the main sources of business cycle synchronisation across a set of highly economically integrated countries. This research aim has a tradition in the literature that studies the conditions of optimum currency areas in terms of business cycle synchronisation. This is highly policy relevant since a considerable degree of business cycle synchronisation between member countries of currency unions is an important prerequisite for a successful operation of monetary policy because of the one-size-fits-all interest rate. Empirical evidence on the channels through which cyclical comovement is induced will add to the knowledge necessary to develop structural policies that improve the efficiency of the single monetary policy.

We extend the previous literature on the determinants of business cycle synchronisation in two dimensions. First, we put special attention on the influence of intensified FDI relations when we identify the impact of the main determinants of business cycle synchronisation, namely trade and financial integration and differences in the sectoral structure. FDI stocks have increased strongly in the past decades, much stronger than trade linkages, and by now a few large multinational firms represent a large share of economic output and employment in many countries (Kleinert et al., 2012). Hence, they provide a basis for strong international linkages through their cross-border activities such as intra-firm trade, firm-wide investment plans or wage setting. In particular for the EMU, foreign direct investments are essential elements for completing the internal market and thus promoting economic integration and overall competitiveness of the region. While economic rationale and research suggest that promoting FDI through investment policies is a valid instrument to remove barriers in order to complete the internal market (Ilzkovitz et al., 2007), theory and available empirical evidence are less clear about the effects of deeper cross-border capital links within a region on business cycle synchronisation. Thus, there could be a potential conflict between European policies that aim at fostering FDI linkages and the efficient policy-making by the European Central Bank (ECB) if member states' cycles tend to move apart because of desynchronising forces of the FDI channel. Studying the question whether two countries that are strongly linked through capital stocks show a higher comovement of output cycles than two countries that are less connected through capital cross-links will clarify such concerns.

Our second contribution to the literature is a more technical one, as we argue below. It is a necessary step forward in the empirics of business cycle synchronisation to use panel instead of cross-section data to identify contemporaneous bilateral relations among the determinants. Previous research mainly focused on data averaged over time and employed cross-section regressions on country (pair) means of the explanatory variables. In such regressions, business cycle synchronisation between two countries is usually measured by the Pearson correlation coefficient of GDP cycles over the entire sample period. Some stud- 
ies impose a panel structure by computing correlation coefficients and averages over few non-overlapping sub-periods of equal size (e.g. Schiavo, 2008; Hsu et al., 2011). These approaches lead to an identification problem if the data are characterised by trends over time since averages become time dependent and the building of arbitrary sub-periods will randomly influence regression results. As will be shown below, in particular trade and FDI intensity measures display strong time trends. A more systematic way of exploiting the between and within variation of the data is to directly run panel regressions and, moreover, take country-pair and period fixed effects into account. Country-pair fixed effects consider unobserved heterogeneity between two countries that arises, for instance, due to geographical or cultural proximity while period-specific effects capture common time shocks. The latter are relevant for distinguishing the transmission of shocks through trade and FDI linkages from common shocks as a source of output cycle synchronisation (e.g. Kappler, 2011). Thus, panel estimations are much more capable of reconciling theory with empiricism than pure cross-sectional or pseudo panel estimation approaches. So far, genuine panel data is used by few studies only (see Kappler, 2011; Kalemli-Ozcan et al., 2013) which focus on one specific determinant of synchronisation.

Our results show that the coefficient of contemporaneous effect of FDI linkages on business cycle synchronisation is in most cases positive significant, but for inner European FDI relations we do no find a significant impact. These findings imply that policies fostering bilateral FDI integration do not harm synchronisation between countries. On the contrary, they may even increase comovement. Furthermore, regarding trade integration, we find it to be in fact not as robust as the cross-section effects reported by previous studies. The correlation between trade relations and synchronisation may be largely driven by common underlying factors. This finding is in accordance with literature highlighting the importance of global shocks (see Kose et al., 2008, 2012; Karadimitropoulou and León-Ledesma, 2013). Finally, increasing heterogeneity in the sector composition between countries is found to have a negative impact on their cyclical synchronisation.

In the next section, we discuss the channels through which FDI may impact on the comovement of business cycles. Furthermore, we provide a short overview on the theoretical motivation and the empirical results for the main determinants of business cycle synchronisation based on the pertinent literature. In Section 3 we introduce our empirical strategy and discuss the advantages of a panel over a cross-sectional approach. Section 4 contains explanations about the measurement concepts and data for the variables of our model. Estimation results and sensitivity tests are presented in Section 5, followed by some concluding remarks in the final section. 


\section{Literature}

Despite the considerable degree of cross-boarder activities arising from foreign direct investment, so far theoretical analyses on the effects of financial integration on business cycles focused almost exclusively on the case of portfolio investment and bank integration. The studies by Russ (2007) and Cavallari $(2007,2008,2010)$ are an exception. These authors integrate heterogeneous firms in a monetary two-country business cycle model, which choose whether to enter a domestic or foreign market and whether to serve foreign markets through trade or through a foreign affiliate according to their productivity. Households participate in firms activity by holding shares of all types of home based firms. Thus, the activities of multinational firms foster the comovement of output across countries by increasing the degree of (dividend) income interdependence.

As regards financial integration in a broader sense, Heathcote and Perri (2002) show that in standard two-country, two-good international real business cycle (IRBC) models the cross-country correlation between output is higher in the case of financial autarky than with the existence of an internationally integrated bond market or complete asset market. In open financial markets, firms can reallocate their resources more efficiently, i.e., to the country with higher productivity, if hit by a shock. Thus, increased financial integration lowers the synchronisation of output. But if investors are subject to binding collateral constraints, Devereux and Yetman (2010) and Devereux and Sutherland (2011) find that comovement differs with respect to the type of financial integration. While integration in bond markets continues to result in lower output correlation in their model, integration in equity markets, where constraints are in place, leads to a transmission of technology shocks across countries through the balance sheet of constrained (international) investors causing output fluctuations to co-move. A similar mechanisms is emphasised by IRBC models incorporating multinational banks, which were developed in the aftermath of the financial crisis of 2007 and 2008 (see Olivero, 2010; Enders et al., 2011; Ueda, 2012). In these studies, financial integration is modeled by financial intermediaries (banks) operating at a global level. In consequence, a negative country-specific shock to the capital of a bank spreads to another country because of binding capital constraints faced by the international bank, which results in comovement of international output fluctuations. In contrast, country-specific technology shocks do not lead to synchronised business cycles just like in a conventional IRBC model such as Backus et al. (1992).

The empirical literature suggests several additional transmission channels of business cycle shocks through multinational firms which are not incorporated into business cycle theory so far. First, FDI gives rise to increasingly international supply chains enhancing 
the spillover of idiosyncratic shocks from one country to another. ${ }^{1}$ Furthermore, Stevens and Lipsey (1992) and Desai and Foley (2006) provide evidence that rates of return and investment of affiliates within a multinational firm are highly correlated, pointing to crossborder investment plans. Budd et al. (2005) and Jansen and Stokman (2006) both come to the same conclusion, though the first study is based on a firm-level panel and the second on macro data: Multinationals share their profits between their affiliates providing a further transmission channel. Balance sheet effects (similar to what Devereux and Yetman, 2010 and Devereux and Sutherland, 2011 propose) may be another transmission channel since the balance sheet of a multinational may be more susceptible to changes in the financial conditions in one of its host countries due to its international exposure (see Desai et al., 2008). But multinational firms may also benefit from their internal capital markets (see Desai et al., 2004) and therefore perform better than local firms under strong financial constraints as Hovakimian (2011) and Alfaro and Chen (2012) point out. Finally, when engaging in business abroad, multinational firms trigger knowledge and technology transfers which in turn may narrow the gap between GDP growth rates.

To summarise, from a theoretical point of view the direction of the influence of FDI on synchronisation is not clear. Most of the possible channels, however, point to a positive relation between FDI integration and cyclical comovement. But as Morgan et al. (2004) point out, the sign of the relation may strongly depend on the type of shock. If the financial sector of a foreign country is hit by a negative shock, a parent company may support its affiliate with financial liquidity. If in contrast there is an adverse shock to productivity, the parent may withdraw its support and shift resources to more profitable locations.

Most empirical studies on the determinants of business cycle synchronisation report a positive impact of financial integration on output comovement irrespective of the measure in use. De-jure measures like composite indices based on the IMF's Annual Report on Exchange Arrangements and Exchange Restrictions (AREAER) ${ }^{2}$ are employed as well as de-facto volume-based or price-based measures like bilateral asset holdings and capital flows or return spreads of equity or bond holdings (see e.g. Kose et al., 2003; Imbs, 2004, 2006; Schiavo, 2008; Keil and Sachs, 2012). In contrast to these studies, Kalemli-Ozcan et al. (2013) use bilateral international bank assets and liabilities and adopt panel methods including country pair and time fixed effects to quarterly data. They detect a strong negative effect of their measure of financial integration on business cycle synchronisation and ascribe this opposing result to an omitted variable bias in cross-section analyses, which could not account for global shocks and unobservable country pair specific heterogeneity. Davis (2014) argues that the integration

\footnotetext{
${ }^{1}$ IRBC models in the spirit of Burstein et al. (2008) capture vertical integration by explicitly including trade in intermediate goods. They find this to be an important channel for synchronisation.

${ }^{2}$ See for instance the Chinn-Ito index (Chinn and Ito, 2008) or the restriction indices by Schindler (2009).
} 
on differing financial markets may lead to different effects on synchronisation depending on whether transmission occurs through the wealth (divergence) or through the balance sheet channel (convergence). According to his estimation results, integration in credit markets occurs mainly through the balance sheet channel yielding a positive effect on comovement. Equity market integration, in contrast, has a negative effect which points to wealth effects as the main transmission channel.

Only few empirical studies investigate the influence of bilateral FDI linkages on comovement of business cycles. Considering the strong growth and large scale of foreign direct investment positions, but also the various potential transmission channels arising from multinational firms discussed above, this economic linkage is more than just a financial link and a relevant factor to be included. Empirical findings by Otto et al. (2001), Hsu et al. (2011), Jansen and Stokman (2011) and Keil and Sachs (2012) lead to the conclusion that the positive effects of increased FDI linkages dominate. The latter two note that there is a shift in importance from trade to FDI in the mid-nineties. Dées and Zorell (2012) in contrast do not find a significant direct impact of FDI which may be due to their unusual unscaled FDI measure.

In addition to FDI linkages, we include as major endogenous factors explaining business cycle synchronisation trade integration and differences in countries' sector structure. Trade linkages are the most reviewed and robust determinant of business cycle synchronisation in the literature. ${ }^{3}$ The positive direct effect of stronger trade relations found in the data is in line with theoretical considerations according to which trade directly links foreign and domestic demand and supply. Thus, trade seems to be an obvious channel for transmission of demand and supply shocks. However, IRBC models have notorious difficulties to match the empirical findings quantitatively (see Kose and Yi, 2006). Comparing estimations over subperiods, Böwer and Guillemineau (2006), Jansen and Stokman (2011) and Keil and Sachs (2012) find that the relevance of trade linkages for bilateral synchronisation has decreased since the mid-nineties. New evidence on the dynamic relationship between synchronisation and trade intensity by Kappler (2011) casts doubt on the importance of trade in the transmission of cyclical shocks. His results support the common-shock view (see e.g. Kose et al., 2008) as they point to common or global factors being the main drivers of synchronisation which trigger changes in trade flows contemporaneously. In this study we focus on the contemporaneous effect of time-varying trade intensity while accounting for common shocks through year specific effects.

Similarities in the sectoral structure of two countries may also be of importance for the bilateral comovement of their business cycles. Countries with a similar industry structure are supposed to exhibit higher comovement other things being equal since they will respond

\footnotetext{
${ }^{3}$ See Frankel and Rose (1998), Imbs (2004), Baxter and Kouparitsas (2005) to cite the most influential.
} 
in similar ways to global and sector-specific shocks. An idiosyncratic shock to a sector in a country will more likely spread to another country if the countries are engaged in related businesses. However, extant empirical evidence on the importance of sectoral similarity is mixed. Differences in the sectoral structure are either found to decrease synchronisation of business cycles significantly (for instance Imbs, 2004, 2006 or Inklaar et al., 2008) or to have no significant impact (see Baxter and Kouparitsas, 2005).

\section{Empirical Approach}

Our estimations to identify the determinants of comovement in cyclical fluctuations are based on the following equation:

$$
\rho_{i j t}=\alpha_{1} F D I_{i j t}+\alpha_{2} T_{i j t}+\alpha_{3} S D_{i j t}+\alpha_{4} I_{1, i j t}+\mu_{i j}+\lambda_{t}+\varepsilon_{i j t},
$$

where $\rho_{i j t}$ is our measure of business cycle synchronisation between country $i$ and country $j$ at time t. $F D I_{i j t}$ denotes the bilateral FDI intensity, $T_{i j t}$ is a measure for trade integration, and $S D_{i j t}$ represents the differences in the sectoral structure within country pairs. These variables are treated as endogenous variables in the following. In $I_{1, i j t}$ we include additional time and country-pair varying exogenous covariates. The disturbances follow a two-way error component model, where $\mu_{i j}$ denotes country-pair specific effects, $\lambda_{t}$ common year specific effects and $\varepsilon_{i j t}$ the remainder stochastic disturbance. A detailed description of all variables and their measurement concepts as well as of their potential impact is given in the next section.

Note that our three endogenous variables may not only directly impact on business cycle synchronisation as described in the previous section, but may also interact with each other and therefore have an indirect impact on synchronisation. To be specific, inter-industry trade integration is supposed to rise as a result of increasing differences in the sector structure to exploit endowment differences or comparative advantages. Intra-industry trade, in contrast, may be fostered by more similar industries. Increased trade integration in turn results in deeper specialisation according to classical trade theory based on comparative advantages and economies of scale. This argument is valid for inter-industry trade. But as pointed out by Frankel and Rose (1998) and Imbs (2004) among others, trade between industrialised countries and especially between European countries is predominantly of the intra-industry type. As such it could be a source for knowledge spillovers similar to FDI and therefore augment similarity. In addition, trade is supposed to have a positive impact on FDI since both are driven by common factors such as the productivity level of firms (see Helpman et al., 2004). Inversely, effects could point in both directions: on the one hand, horizontal FDI may substitute trade where trade costs are prohibitively high or firms want to be closer to the 
customer, on the other hand vertical FDI (i.e., off-shoring parts of the production) or exportplatform FDI may stimulate trade in intermediate as well as in final goods. ${ }^{4}$ Finally, higher similarity may stimulate new FDI in order to benefit from technological knowhow abroad, to be closer to the costumer or to reduce transport costs. The impact of FDI linkages on the industry composition is, however, ambiguous. Due to FDI induced technology transfer, countries might become more similar with respect to their industry composition, whereas the slicing of the supply chain and the possibility to diversify risks gives rise to a higher degree of specialisation.

To take these indirect effects into account, Imbs (2004) proposed the estimation of a system of equations. In addition to the equation explaining the bilateral comovement of business cycles, such a system contains one equation for each endogenous variable. Thus, equation (1) could be amended by the following equations

$$
\begin{aligned}
F D I_{i j t} & =\beta_{1} T_{i j t}+\beta_{2} S D_{i j t}+\beta_{3} I_{2, i j t}+u_{2, i j t} \\
T_{i j t} & =\gamma_{1} F D I_{i j t}+\gamma_{2} S D_{i j t}+\gamma_{3} I_{3, i j t}+u_{3, i j t} \\
S D_{i j t} & =\delta_{1} F D I_{i j t}+\delta_{2} T_{i j t}+\delta_{3} I_{4, i j t}+u_{4, i j t}
\end{aligned}
$$

where each endogenous determinant depends on the other endogenous variables and on exogenous factors $I_{m, i j t}$ with $m=2,3,4$ being the index of the additional equation. By analogy with equation (1) the disturbances $u_{m, i j t}$ are modelled as a two-way error components structure:

$$
u_{m, i j t}=\mu_{m, i j}+\lambda_{m, t}+\varepsilon_{m, i j t} .
$$

Note, however, that we do not estimate the whole system of equations. We focus on identifying the direct effects of the determinants of comovement in business cycles, i.e. we estimate only equation (1) by means of a two-stage least squares approach. Nevertheless, we take the whole system into account when instrumenting, since the instruments stem from the exogenous variables $I_{m, i j t}$ with $m=2,3,4$ included in equations (2) to (4). Even if we do not estimate equations (2) to (4) “... much can be gained in specifying a system of simultaneous equations as it permits identification of the coefficients of endogenous regressors using as instruments exogenous regressors excluded from the equation of interest.", as Cameron and Trivedi (2005, p.762) state.

We acknowledge that an estimation of equations (2) to (4) would nevertheless be useful to disentangle the indirect effects of the determinants resulting from their interdependence. We would for example know whether trade linkages indirectly foster synchronisation by enhancing FDI or decrease the differences in the sector composition. In an attempt to identify these relations, we came across the same problem for all three equations: Our available

\footnotetext{
${ }^{4}$ For a analysis of the two-way linkages between FDI and trade see Aizenman and Noy (2006).
} 
instrument sets (see Subsection 4.2) were rejected by Hansen's J test in almost all cases. One of the possible reasons may be the close relation of trade and FDI, which are determined by very similar factors. This makes it difficult to find an instrument which is correlated with one and exogenous to the other of the two variables. If the exogeneity condition for the instruments is not met, inconsistently estimated coefficients are the consequence. Therefore, we refrain from estimating non properly identified indirect effects and from an estimation of the whole system with a three-stage least squares (3SLS) estimator. ${ }^{5}$ Previous studies reporting estimates for the indirect relations either worked with exactly identified systems where overidentifying tests can not be applied assuming the exogeneity or without reporting tests of their instrumentation (see Imbs, 2004, 2006; Schiavo, 2008; Inklaar et al., 2008; Hsu et al., 2011; Dées and Zorell, 2012; Keil and Sachs, 2012).

In our analysis, we first conduct estimations based on a collapsed cross-section sample with observations pooled over time in keeping with many previous studies. A pure crosssection or between identification strategy employing means of time-varying variables, however, is subject to several objections. Identification over the variation in long-term average behaviour between country pairs is based on the assumption of a stable relation between the variables over time. Several studies like Frankel and Rose (1998), Inklaar et al. (2008) or Keil and Sachs (2012) deal indirectly with the concern of missing stability by splitting their samples into subperiods (which serves in Inklaar et al. (2008) also to generate more observations). If results for subperiods are considered separately, they point to a change in the importance of trade and FDI over time, corroborating this concern. As we show below, measures of trade and FDI integration contain strong trends in their behaviour over time. Thus, an interpretation of their means over the long term is highly questionable. Applying panel estimation methods allows to capture the within variation in the data. In addition, crosssection estimates may suffer from omitted variable bias, since some variables of interest are not observable and a sound theoretical foundation of the estimated equation is not at hand. Using panel data enables us to mitigate this problem by taking unobservable country-pair specific effects into account which capture time invariant explanatory factors. Furthermore, we introduce year specific effects to control for common shocks to both countries. This is an important aspect in the light of the strong global shocks of the last years and cannot be tackled in a cross-section approach. Cross-section data does not allow to disentangle whether higher comovement is caused by transmission of idiosyncratic shocks, e.g. through trade, or by common shocks. Hence, the impact of a strong global shock may in the cross-section view be interpreted as stronger economic integration, i.e., increased transmission, because the variables of interest contemporaneously move in the same direction.

\footnotetext{
${ }^{5} \mathrm{~A}$ 3SLS estimator, which takes contemporaneous correlations across equations into account and is thus more efficient, would suffer from a bias due to inconsistent estimation of single equations in the system.
} 
For these reasons, in the main part of our analysis, we estimate the equation explaining synchronisation with an appropriate panel instrumental variable approach. We employ the error component two-stage least squares (EC2SLS) estimator proposed by Baltagi (1981) and expounded in Baltagi (2008), which is a random effect 2SLS estimator based on a weighted average of fixed effects and between 2SLS estimators. It differs from a conventional random effects or generalised 2SLS estimator in taking into account not only endogeneity stemming from correlations between country-pair fixed effects and explanatory variables but also endogeneity between the explanatory variables as described by equations (2) to (4). ${ }^{6}$

\section{Measurement Concepts and Data}

\subsection{Business Cycle Synchronisation and its Endogenous Determi- nants}

We measure bilateral synchronisation of business cycles $\rho_{i j t}$ as the negative absolute difference between two countries' real GDP growth rates following Giannone and Reichlin (2008), Kappler (2011) and Kalemli-Ozcan et al. (2013): ${ }^{7}$

$$
\rho_{i j t}=-\left|\Delta Y_{i t}-\Delta Y_{j t}\right|
$$

This approach has an interpretation similar to the Pearson correlation coefficient-higher levels of $\rho_{i j t}$ indicate a higher degree of bilateral synchronisation between country $i$ and $j$ in year $t$. But it has several advantages over this traditional time-invariant correlation measure of business cycle synchronisation. First, it reveals the variation in synchronisation over time. Thereby the stationary nature of synchronisation becomes evident. ${ }^{8}$ Second, $\rho_{i j t}$ is independent of the underlying sample period for each $t$, which is not the case for the meanbased correlation coefficient as used in most studies, even if it is estimated over subperiods or a rolling window. In addition, our growth rate based measure is not subject to measurement errors and to critiques on filtering methods which applies to estimated measures of business cycles, e.g. by the HP filter, and their correlations.

When measuring bilateral FDI and trade integration, we want to capture the economic importance of these linkages for both countries. Therefore, we apply the following measure-

\footnotetext{
${ }^{6}$ The EC2SLS estimator employs more instruments than the G2SLS estimator by exploiting the restrictions in the error-component structure of the variance-covariance matrix and is thus more efficient (see Baltagi, 1981).

${ }^{7}$ Detailed information on data sources are listed in Appendix A.

${ }^{8}$ This applies not only to the synchronisation measure used in our study but also to other time-variant synchronisation measures proposed in literature, namely by Yetman (2011), Mink et al. (2007), Morgan et al. (2004) and Alesina et al. (2003).
} 
ment concept

$$
\begin{aligned}
T_{i j t} & =\frac{E X_{i j t}+I M_{i j t}}{G D P_{i t}+G D P_{j t}} \\
F D I_{i j t} & =\frac{O u t_{i j t}+I n_{i j t}}{G D P_{i t}+G D P_{j t}},
\end{aligned}
$$

where bilateral export and import flows and FDI inward and outward stocks, respectively, ${ }^{9}$ are scaled by the sum over the GDP of both countries. ${ }^{10}$ So as long as a shock affects trade or FDI and output proportionally, we observe no change in our intensity measure. We prefer FDI stocks to flows, since the latter are of minor relevance with respect to their size (relative to GDP). Furthermore, being mainly the adjustment of existing FDI relations, they are just one of the channels through which existing multinationals affect business cycle comovement. As described in detail in Section 2, the existence of FDI stocks/multinational firms opens up several transmission mechanisms from international supply chains to technology transfer including intra-firm investment and finance which constitute FDI flows. The stronger the linkages between countries in terms of FDI stocks, the stronger these channels may work.

To capture differences in the sectoral structure between countries we resort to value added shares $s_{z i t}$ for the sectors $z=(1, \ldots, Z)$ of the OECD STAN database covering all economic activities (including services) according to the International Standard Industrial Classification (ISIC) rev. 3 to compute

$$
S D_{i j t}=\sum_{z=1}^{Z}\left|s_{z i t}-s_{z j t}\right| .
$$

This measure is equal to zero if countries have an identical sector structure and reaches its maximum of two for completely disjunct sectors. ${ }^{11}$ We expect a negative coefficient in our estimation since larger differences in the sector structure between two countries should decrease their degree of synchronisation as they make the transmission of idiosyncratic shocks less likely.

\footnotetext{
${ }^{9}$ With respect to data on bilateral trade flows and FDI stocks, we follow the approach proposed by Feenstra et al. (2005): since in practice $E X_{i j t}=I M_{j i t}$ and $O u t_{i j t}=I n_{j i t}$ does not hold, we use the data from the importing/inward FDI country if available which is assumed to be more reliable.

${ }^{10}$ In some studies total trade flows/FDI positions of both countries are used as scaling factor. The resulting measures have a different interpretation from ours: they capture the importance of a particular bilateral trade/FDI relation relative to overall trade/FDI of these countries. Thus, these measures assign the same importance to large trade flows between very open countries and small trade flows between relatively closed countries with small overall trade. We think that it is the economic value of linkages which matters for synchronisation and not their share in countries' overall linkage portfolio.

${ }^{11}$ Note that we calculate $S D_{i j t}$ only for country pairs and years where the database covers at least $50 \%$ of the economy wide value added.
} 


\subsection{Exogenous Variables and Instruments}

Equation (1) as well as equations (2) to (4) include a set of exogenous explanatory variables denoted by $I_{m, i j t}$. While variables in $I_{1, i j t}$ are exogenous explanatory variables for our equation of interest, all variables included in $I_{2, i j t}$ to $I_{4, i j t}$ but not in $I_{1, i j t}$ serve as instruments for the identification of the coefficients of endogenous regressors in the synchronisation equation. In the following we describe the set of variables in all $I_{m, i j t}$.

In the synchronisation equation (1) we include in $I_{1, i j t}$ bilateral measures comparing monetary and fiscal policy within country pairs. The discrepancy in monetary policy between countries is captured by absolute differences between short term interest rates. This measure is the higher, the higher the discrepancy between monetary policies, whereas for country pairs which are both in the euro area it becomes zero ${ }^{12}$. Coordinated monetary policy may increase synchronisation by enhancing similar reactions to a common shock or being itself the source of a common shock. In a currency union, the stability of the exchange rate may provide an additional indirect positive effect by stimulating trade integration. But in case of idiosyncratic shocks, countries under a common monetary policy may lack the possibility of adjustment to keep cycles moving together. Empirical studies find only weak evidence for similarity in monetary policy as an enhancing factor (see Baxter and Kouparitsas, 2005). Divergence in fiscal policy is measured as bilateral differences in the government budget balance in percentage of GDP following Darvas et al. (2007). From a theoretical point of view, the effect of fiscal policies on synchronisation is ambiguous depending on the type of economic shock and on the type of fiscal policy. On the one hand, discretionary or rulebased fiscal spending may be used to dampen the effects of country-specific or asymmetric shocks implying a positive impact of fiscal divergence on cyclical comovement. On the other hand, fiscal policy may also be employed in a pro-cyclical way or even be the source of a country-specific shock and therefore loosen comovement. Empirical studies of Darvas et al. (2007) or Inklaar et al. (2008) suggest that a higher discrepancy between fiscal deficits has at best a negative effect on the comovement of business cycles or none as Clark and Van Wincoop (2001) find. Although previous literature (see Inklaar et al., 2008) based on cross-section identification shows that there are no major differences in the results between an exogenous and an endogenous treatment of these two policy variables, the assumption of no contemporaneous reaction of policy to cyclical fluctuations does not necessarily hold in a panel model. We therefore consider an alternative specification where we include both policy variables with a lag of one year instead of the contemporaneous variables. For the

\footnotetext{
${ }^{12}$ Differences in the short term interest rates may be seen as the lower bound of overall differences in monetary policy. The extraordinary country specific measures used by the ECB in the last years show that there may be additional differences even within a currency union, at least during times of crisis. In consequence, the coefficient of monetary policy has to be interpreted as the upper bound.
} 
lagged variables the assumption of exogeneity is justifiable from a theoretical point of view. Furthermore, it is known that business cycles usually react with a lag to changes in fiscal and monetary policy. Qualitatively, there is virtually no difference in the results between including the contemporaneous and the lagged values of the policy variables. At the same time, a noteworthy change in the size of coefficients is observed for FDI integration which results to be about $25 \%$ higher in some specifications when lagged policy measures are used.

As instruments for the endogenous regressors (and as covariates for the remaining equations) previous papers employ mainly time-invariant country pair specific variables like the well-established gravity variables for trade or the indicators on the degree of de jure financial openness by La Porta et al. (1998) for financial integration. In our panel estimation approach all time-invariant explanatory factors are absorbed by country pair fixed effects. Therefore, by our research design only time-variant variables are considered as instruments.

Theoretically, an optimal candidate for $I_{2, i j t}$ as an instrument and exogenous explanatory variable for FDI integration would be a de jure measure of openness to FDI. As a change in GDP growth is unlikely to cause a contemporaneous regulatory change, it can be assumed that a bilateral version of a de jure measure of FDI but also trade openness is uncorrelated to the synchronicity measure. The OECD provides an index on FDI Regulatory Restrictiveness, but unfortunately only for a few years. ${ }^{13}$ But even more comprehensive data on the legal situation like the indices by Schindler (2009) on direct investment restrictions or the more general Chinn-Ito index (Chinn and Ito, 2008) measuring the degree of capital account openness are problematic for panel data analyses since their within variation is low for most countries and thus their explanatory power is limited. If we include one of these variablestransformed into a bilateral measure by taking sums or differences - in $I_{2, i j t}$ our regressions return an insignificant effect in the first stage no matter in which estimation specification, while the coefficients of the second stage do not change. Therefore, we do not include any de jure measure of capital or FDI openness in $I_{2, i j t}$. Instead we use indicators for de facto capital controls to explain the degree of bilateral FDI linkages. A better general access to capital in each single country may be an important criterion for direct investment decisions and therefore be favourable to FDI integration. The same holds true for trade integration. Since the following measures are not based on truly bilateral data but are computed by taking differences or sums of indicators for overall capital openness of each of the two countries, it seems reasonable to assume their exogeneity with respect to bilateral FDI integration. We include the bilateral sum of the gross private capital flow ratio to GDP as a volume-based measure of capital openness. As an alternative, we use a price-based measure, namely the return spread between share price indices which are constructed to represent share price movements in national stock markets. According to theory, in perfectly integrated

\footnotetext{
${ }^{13}$ The index is provided for the years 1997, 2003, 2006 and on an annual basis since 2010.
} 
capital markets the law of one price should hold, implying equal returns on comparable assets (Keil and Sachs, 2012). Smaller return spreads indicating a higher degree of financial market integration are therefore expected to foster FDI integration. Additionally, we include lagged FDI integration as suggested by Schiavo (2008) and a measure of overall economic development of a country pair given by the bilateral sum of GDP per capita.

In explaining trade integration with panel data we can build on an established literature. We follow Egger (2000) in including the following index measuring the similarity in the economic size of countries in $I_{3, i j t}$ :

$$
G_{\text {DPimilar }} \text { sit }=1-\left(\frac{G D P_{i t}}{G D P_{i t}+G D P_{j t}}\right)^{2}-\left(\frac{G D P_{j t}}{G D P_{i t}+G D P_{j t}}\right)^{2} .
$$

This index is the larger, the more similar two countries are in terms of GDP. Very similar countries are supposed to have a high degree of intra-industry trade and therefore also of general trade linkages. Furthermore, $I_{3, i j t}$ contains the same measure of overall economic development like $I_{2, i j t}$. Additionally, we include an index on the degree of bilateral (de jure) economic integration which is taken from the Database on Economic Integration Agreements by Baier and Bergstrand (2007), but which is only available until 2005.

Differences in the sector structure are explained by overall economic development (like trade and FDI linkages) and by differences in economic development/wealth between countries measured by the absolute difference in GDP per capita. These two measures both draw on the idea that economies manifest certain patterns regarding the industrial composition in different states of development (Imbs and Wacziarg, 2003). This argument may be less appropriate the more similar countries are with respect to their sectoral structure and stage of development.

For most of the described instruments it is not possible to completely exclude a correlation with our measure of bilateral cyclical comovement between countries by theory. Therefore, we test the validity of instruments by means of Hansen's J test, i.e., testing the validity of overidentifying restrictions. In contrast to the Sargan test, this test is consistent in the presence of heteroscedasticity. Note that for panel random effect estimators Hansen's J test can even be applied if there is only one instrument for each endogenous determinant. When applying the EC2SLS estimator, the exogenous regressors (in our case the indicators for monetary and fiscal policy as well as all year dummies) are subject to a GLS transformation before the estimation. In the IV estimation (on the transformed data) the transformed regressors are all treated as endogenous while for each of them their demeaned and recentered transformation as well as their group mean transformation are used as excluded instruments. In contrast, for a fixed effects 2SLS estimator, where such a transformation is not used, the test is not applicable in this case since the equation is just identified. In addition, we control the first stage F-statistics to prevent using a weak instrument set. 

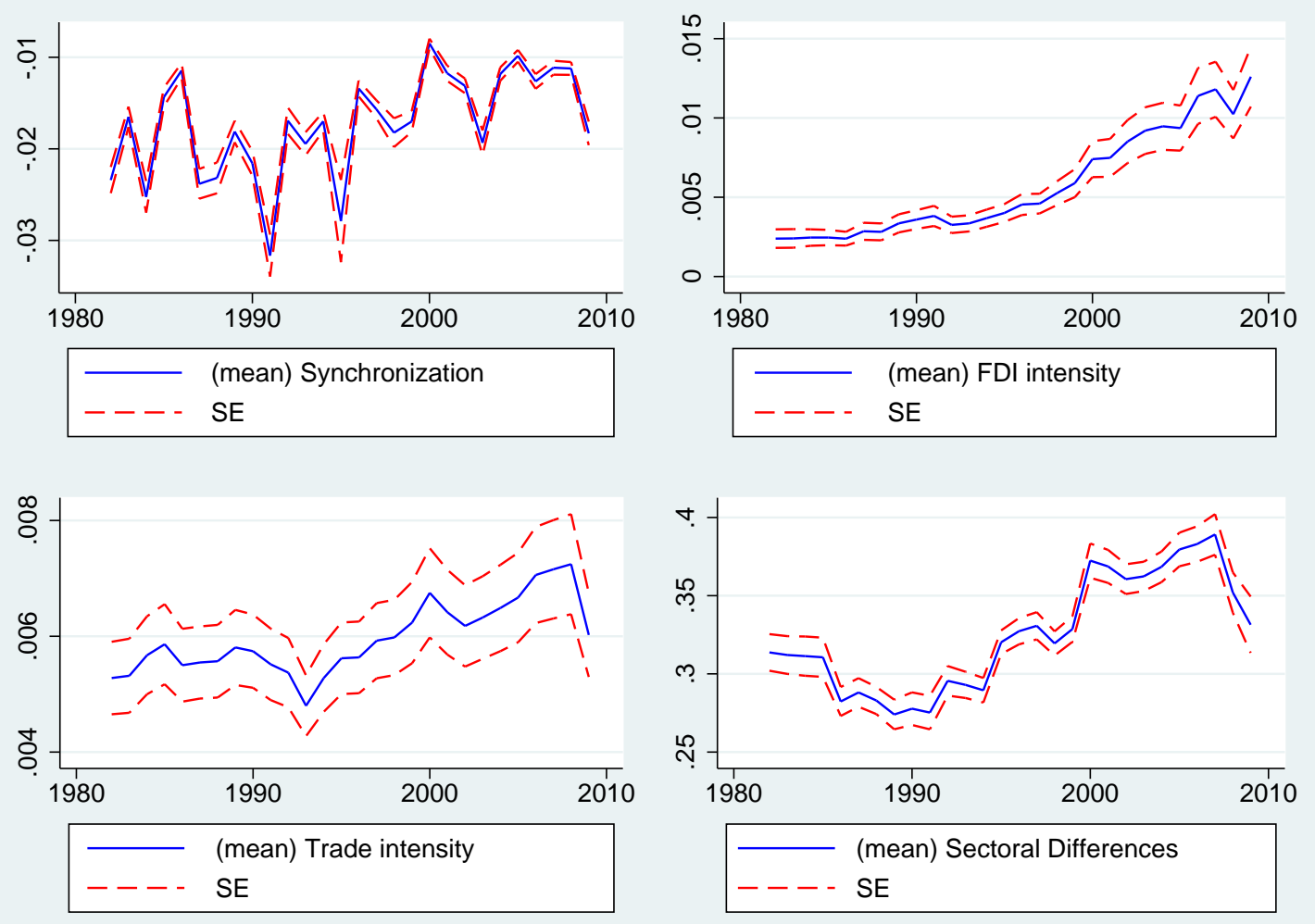

Figure 1: Cross-Sectional Means of Business Cycle Synchronisation and its Endogenous Determinants

\subsection{Data Overview}

Since the emphasis of our identification approach lies on the within variation in the data, we choose the longest possible sample at the expense of a reduction of the number of country pairs. After the exclusion of South Korea because of its strongly differing synchronisation patterns, there are 16 countries left yielding 120 country pairs. ${ }^{14}$ Due to the limitations in time range given by the OECD's bilateral FDI data and the OECD STAN database used to calculate sectoral differences, we obtain a usable data set for the period from 1982 to 2009 at an annual frequency. The panel is unbalanced, however, with an increasing number of observations for more recent years. Descriptive statistics for all variables are included in the Appendix A in Table 5.

In Figure 1 we plot cross-section averages for each point in time of our synchronisation measure and the three endogenous determinants. The plots reveal that all variables but synchronisation exhibit significant changes in levels over time, casting the meaningfulness of

\footnotetext{
${ }^{14}$ These countries are: Austria, Canada, Denmark, Finland, France, Germany, Greece, Italy, Japan, Netherlands, Norway, Portugal, Spain, Sweden, UK, US.
} 
long-term averages into doubt as they vary with the underlying period.

\section{Results}

In this section, we briefly report what a cross-section approach would imply for our data set before we present detailed estimation results for the panel dimension. With respect to the instrumentation, we start with a parsimonious specification where we include one (timevariant) instrument for each endogenous variable. These instruments are the volume-based measure of capital openness, economic similarity and overall economic development. ${ }^{15}$ In the following, we discuss and test the choice of instruments by employing the other available instruments discussed before.

\subsection{Cross-Section}

Before conducting panel estimates, we confront our data basis with the cross-section based literature. We do this by estimating the synchronisation equation with cross-section data obtained by averaging the data over time. ${ }^{16}$ To make the comparison more appropriate, we additionally include a set of time-invariant exogenous variables. Our identification approach based on time-variant instruments presented in Section 4.2 cannot correctly identify effects in the cross-section where fixed effects cannot be taken into account. In such a setting, we obtain low F-statistics for FDI and trade integration in the first stage pointing to weak instruments. Including some time-invariant variables serves to at least partially control for country-pair specific characteristics. We use standard gravity variables, namely the distance between the main economic centers and dummy variables for common borders from CEPII's GRAVITY dataset ${ }^{17}$, as well as the bilateral sum of an index measuring share holder rights provided by La Porta et al. (1998). These additional variables remedy the weak instruments problem in the cross-section raising the F-statistics of first step estimations well above the rule of thumb value of 10 . In addition, Hansen's J test does not report problems with the validity of the instruments. Estimations are carried out based on pooled data over the entire period from 1982 to 2009 as well as over the subperiods 1982-1998 and 1999-2009, that is before and after the introduction of the euro.

We find that coefficients - especially those of trade and FDI intensity — vary strongly with

\footnotetext{
${ }^{15}$ Note, however, that the instruments are not assigned one by one to the single determinants by means of the estimator, but are all together used in each first-stage regression explaining the endogenous.

${ }^{16}$ This is the common procedure in the cross-section literature for all time-variant variables. Bilateral synchronisation, however, is usually calculated as the Pearson correlation coefficient between business cycles of two countries.

${ }^{17} \mathrm{http}: / /$ www.cepii.fr/CEPII/en/bdd_modele/bdd.asp
} 
the underlying sample period. The shift in the coefficients over time does not necessarily have to be a signal for a change in the strength of the underlying relation between FDI or trade linkages and synchronisation but may simply be driven by the calculation of means over time series containing trends. In addition, multicollinearity between FDI and trade may be a big concern in the cross-section as we will show in detail in the next section. Thus, we refrain from further interpreting the results which are reported in Table 6 in Appendix B.

\subsection{Panel Approach}

In this subsection we discuss the results of estimating equation (1), employing the error component two-stage least squares (EC2SLS) estimator on panel data. All panel estimations include country-pair specific effects and a full set of year dummies if not stated differently. Hence, they focus on the transmission channels of idiosyncratic business cycle shocks.

Basic Specification with Parsimonious Instrument Set The results of our basic specification with the parsimonious time-variant instrument set as described at the beginning of this section are reported in Table 1 column (1). The estimation points to a significant positive influence of FDI integration implying that the synchronising effect dominates among the various cross-boarder linkages in multinational firms. We do not find a significant impact of trade relations on the comovement of business cycles. As we will show in the following, the coefficient of trade integration is insignificant not only in our basic specification but also in all alternative specifications. Differences in the sectoral structure in turn have a negative significant effect on cyclical comovement implying that the transmission of idiosyncratic shocks between countries is the weaker, the bigger the differences in their sectoral structure. Therefore, FDI and trade possibly exert an indirect influence on business cycle synchronisation by causing changes in the sectoral composition of economies. Differences in monetary policy are estimated to have a negative impact on the cyclical comovement of a country pair implying higher synchronisation in countries with similar short term interest rates. In contrast, differences in the net lending position of governments have a positive effect. This result may arise from the fact that governments incur debts when trying to buffer their country from idiosyncratic shocks.

To validate our identification approach, we first checked the F-statistics of the EC2SLS (and fixed effect two stage least squares, FE2SLS) first stage regressions. These signal no problems of weak instrumentation for any of the endogenous covariates being all two-digit. In addition, we find F-statistics from FE2SLS estimations to be higher than the single-digit F-statistics of first stage between regressions emphasising that country pair specific effects should not be neglected (see Baltagi, 2008). Second, we test the exogeneity of instruments by means of Hansen's J test which is reported in the lower part of Table 1. The degree of 
Table 1: Business Cycle Synchronisation: EC2SLS with Varying Instruments

\begin{tabular}{llllll}
\hline \hline & $(1)$ & $(2)$ & $(3)$ & $(4)$ & $(5)$ \\
Instrumentation & Parsim. & Econ. Diff. & Return Spread & EIA & L.FDI \\
Period & $1982-2009$ & $1982-2009$ & $1982-2009$ & $1988-2005$ & $1983-2009$ \\
\hline FDI & 0.249 & 0.269 & 0.285 & 0.489 & -0.011 \\
& $(0.124)^{* *}$ & $(0.134)^{* *}$ & $(0.123)^{* *}$ & $(0.168)^{* * *}$ & $(0.059)$ \\
Trade & -0.157 & -0.172 & -0.194 & -0.204 & 0.069 \\
& $(0.198)$ & $(0.218)$ & $(0.192)$ & $(0.226)$ & $(0.160)$ \\
Sectoral Differences & -0.039 & -0.037 & -0.038 & -0.032 & -0.040 \\
& $(0.009)^{* * *}$ & $(0.009)^{* * *}$ & $(0.008)^{* * *}$ & $(0.009)^{* * *}$ & $(0.009)^{* * *}$ \\
Monetary Policy & -0.097 & -0.095 & -0.096 & -0.093 & -0.083 \\
& $(0.024)^{* * *}$ & $(0.024)^{* * *}$ & $(0.024)^{* * *}$ & $(0.026)^{* * *}$ & $(0.024)^{* * *}$ \\
Fiscal Policy & 0.064 & 0.063 & 0.064 & 0.059 & 0.054 \\
& $(0.012)^{* * *}$ & $(0.012)^{* * *}$ & $(0.012)^{* * *}$ & $(0.015)^{* * *}$ & $(0.012)^{* * *}$ \\
Year Dummies & Yes & Yes & Yes & Yes & Yes \\
\hline$N$ & 1,793 & 1,793 & 1,791 & 1,447 & 1,750 \\
Hansen's J Test & & & & & \\
$\chi^{2}$ (d.f.) & $19.98(25)$ & $17.39(27)$ & $29.59(27)$ & $26.21(21)$ & $21.26(28)$ \\
p-value & 0.748 & 0.921 & 0.333 & 0.198 & 0.814 \\
\hline \hline
\end{tabular}

Notes: Standard errors in parentheses; ${ }^{* * *} \mathrm{p}<0.01,{ }^{* *} \mathrm{p}<0.05,{ }^{*} \mathrm{p}<0.1$.

freedom of the $\chi^{2}$ distribution is given by the number of exogenous time-varying variables after the transformation. The result of Hansen's J test on the EC2SLS estimations confirms the validity of our parsimonious instrumentation. In addition, we apply a Hausman test based on the difference between FE2SLS and EC2SLS estimates. It turns out that the null hypothesis of consistent EC2SLS estimations cannot be rejected for this and any of the following specifications.

Alternative Instrumentation In order to test the dependence of our results on the instrumentation, we add the alternative instruments discussed in Subsection 4.2 one-byone to the parsimonious instrument set. In Table 1 we report the estimation results as well as the test statistics of Hansen's J Test. We add in turn the measures of differences in economic development (column 2), differences in return spreads (column 3) and the indicator on Economic Integration Agreements (EIA) (column 4) and finally lagged FDI intensity 
(column 5) to the instrument set. ${ }^{18}$ The changes in the instrumentation do not come with significant changes in the results reported for the parsimonious specification except for the FDI coefficient when including EIA or lagged values of FDI. In the first case, the impact of FDI is bigger, which is due to the data limitations of the EIA indicator. As mentioned in Subsection 4.2, it stops in 2005 so that the crisis-driven years since 2007 are excluded from the sample. The recent global crisis has provoked a particularly sharp plunge in FDI stocks among industrialised countries (see Figure 1) which might be the reason behind the higher coefficients in the shorter sample. When we estimate the parsimonious specification excluding the years from 2007 onwards from the sample, we also obtain a higher coefficient for FDI (0.397) at a $1 \%$ significance level but no remarkable changes regarding the other variables (not reported). Including lagged FDI integration as an instrument yields an insignificant effect of FDI integration on business cycle synchronisation.

Relation of FDI and Trade A potential reason for the insignificant effects of trade integration could be its multicollinearity with FDI. Indeed, in the cross-section we observe an unconditional correlation as high as 0.71 between the two variables, which makes crosssection based estimations including trade and FDI even more questionable. In the panel data the unconditional correlation still amounts to 0.65 , but drops to 0.44 when we take country-pair fixed effects into account and to 0.37 when, additionally, year specific effects are included. Considering the correlation between country pairs and within country pairs separately, it emerges that the high correlation is mainly driven by strong relations between trade and FDI across country pairs, but not over time. The correlation between country pairs amounts to 0.69 averaged over all years, whereas the correlation over time adds up to just 0.31 averaged over all country pairs (a detailed statistic on between and within correlation is included in Appendix B, Figure 2 and 3). This said, multicollinearity seems to be more of an issue when we look at shorter samples or at the cross-section.

As a further test of the importance of multicollinearity for our estimation results, we compute estimations excluding in turn trade and FDI. To stick with our instrumentation approach we drop GDP similarity and global capital openness, respectively, from the instrument set in this step. But very similar results are obtained when keeping all instruments from the parsimonious specification. In the first case, we obtain a somewhat smaller but significant coefficient for FDI linkages in the synchronisation equation leaving the remaining results qualitatively unchanged (see Table 2, column 1). Excluding FDI instead leads to greater changes: the trade coefficient becomes positive but remains insignificant. If we restrain the sample to more recent years, though, the coefficient becomes significant but results

\footnotetext{
${ }^{18}$ In addition, we tried various combinations of bigger instrument sets, but in most of the cases Hansen's $\mathrm{J}$ test rejected these bigger instrument sets.
} 
Table 2: Business Cycle Synchronisation: EC2SLS Excluding Trade/FDI and Restricted Country-Pair Samples

\begin{tabular}{lll|lll}
\hline \hline & $(1)$ & $(2)$ & $(3)$ & $(4)$ & $(5)$ \\
Country Group & OECD & OECD & OECD & EU & EMU \\
Period & $1982-2009$ & $1982-2009$ & $1988-2009$ & $1988-2009$ & $1988-2009$ \\
\hline FDI & 0.186 & & 0.249 & 0.183 & 0.169 \\
& $(0.088)^{* *}$ & & $(0.115)^{* *}$ & $(0.182)$ & $(0.321)$ \\
Trade & & 0.160 & -0.137 & -0.169 & 0.116 \\
& & $(0.128)$ & $(0.183)$ & $(0.267)$ & $(0.435)$ \\
Sectoral Differences & -0.037 & -0.035 & -0.040 & -0.050 & -0.053 \\
& $(0.009)^{* * *}$ & $(0.009)^{* * *}$ & $(0.008)^{* * *}$ & $(0.022)^{* *}$ & $(0.027)^{*}$ \\
Monetary Policy & -0.089 & -0.058 & -0.101 & -0.172 & -0.236 \\
& $(0.023)^{* * *}$ & $(0.023)^{* *}$ & $(0.024)^{* * *}$ & $(0.036)^{* * *}$ & $(0.055)^{* * *}$ \\
Fiscal Policy & 0.063 & 0.055 & 0.063 & 0.089 & 0.085 \\
& $(0.012)^{* * *}$ & $(0.012)^{* * *}$ & $(0.012)^{* * *}$ & $(0.022)^{* * *}$ & $(0.034)^{* *}$ \\
Year Dummies & Yes & Yes & Yes & Yes & Yes \\
\hline$N$ & 1,793 & 1,802 & 1,763 & 1,014 & 574 \\
Hansen's J Test & & & & & \\
$\chi^{2}$ (d.f.) & $18.65(24)$ & $24.5(24)$ & $21.14(23)$ & $14.52(19)$ & $9.30(15)$ \\
p-value & 0.770 & 0.433 & 0.573 & 0.753 & 0.861 \\
\hline \hline
\end{tabular}

Notes: Standard errors in parentheses; ${ }^{* * *} \mathrm{p}<0.01,{ }^{* *} \mathrm{p}<0.05,{ }^{*} \mathrm{p}<0.1$.

are more sensible to the choice of instruments. These results imply that trade effects are not completely irrelevant for the synchronisation of business cycles. But the impact of trade may be more of the indirect type, i.e., by fostering stronger FDI linkages and influencing the degree of sectoral differences between economies. Taking FDI out of the system eliminates the first of these indirect channels and results in a weak direct impact of trade.

Synchronisation in the EU and EMU We also investigate whether our conclusions from the entire sample, which is based on selected OECD countries, hold for the European environment. Therefore, we re-estimate the equation for two smaller country samples, the first limited to country pairs in the European Union (EU) and the second including only relations between euro area members (EMU). Since before 1988 there is no bilateral inner European data available for some of the variables, we report the results for this shorter time frame for all country groups. Estimated coefficients are presented in Table 2 column (3)-(5). They imply very similar results for synchronisation in the EU and the EMU. In contrast 
Table 3: Business Cycle Synchronisation: EC2SLS Parsimonious Specification for Subperiods

\begin{tabular}{llll}
\hline \hline & $(1)$ & $(2)$ & $(3)$ \\
Period & $1982-2009$ & $1982-1998$ & $1999-2009$ \\
\hline FDI & 0.249 & 0.585 & 0.199 \\
& $(0.124)^{* *}$ & $(0.404)$ & $(0.089)^{* *}$ \\
Trade & -0.157 & -0.052 & -0.050 \\
& $(0.198)$ & $(0.344)$ & $(0.152)$ \\
Sectoral Differences & -0.039 & -0.053 & -0.017 \\
& $(0.009)^{* * *}$ & $(0.013)^{* * *}$ & $(0.007)^{* *}$ \\
Monetary Policy & -0.097 & -0.137 & 0.008 \\
& $(0.024)^{* * *}$ & $(0.034)^{* * *}$ & $(0.029)$ \\
Fiscal Policy & 0.064 & 0.021 & 0.036 \\
& $(0.012)^{* * *}$ & $(0.024)$ & $(0.012)^{* * *}$ \\
Year Dummies & Yes & Yes & Yes \\
\hline$N$ & 1,793 & 681 & 1,112 \\
Hansen's J Test & & & \\
$\chi^{2}$ (d.f.) & $19.98(25)$ & $21.19(16)$ & $15.97(13)$ \\
p-value & .748 & .172 & .255 \\
\hline \hline
\end{tabular}

Notes: Standard errors in parentheses; ${ }^{* * *} \mathrm{p}<0.01,{ }^{* *} \mathrm{p}<0.05,{ }^{*} \mathrm{p}<0.1$.

to the OECD sample, the impact of FDI is insignificant. Thus, it seems that positive and negative effects of inner European FDI linkages on business cycle synchronisation between member countries cancel out on aggregate. So increasing intensity of FDI neither fosters nor harms convergence of business cycles between European countries.

Since monetary policy in the euro area is uniform after the introduction of the single currency, we re-estimate equation (1) without including differences in monetary policy as exogenous explanatory variable. The estimated coefficients change only marginally compared to the baseline specification, therefore we refrain from reporting them for the sake of space.

Subperiods In contrast to the cross-section, estimates of the baseline specification for the recent period from 1999 to 2009 do not strongly differ from the overall sample (see Table 3). In essence, differences in monetary policy are not significant in this subsample, which is not surprising given that 9 out of our 16 countries are subject to the single interest rate of the EMU. In the period before the introduction of the euro we find an insignificant coefficient for fiscal policy and for FDI integration. That FDI linkages have no impact on business cycle synchronisation in the earlier period, fits the data (see Figure 1), according to which 
bilateral FDI relations start to intensify around the mid-nineties. It also goes with the crosssection evidence by Jansen and Stokman (2011) and Keil and Sachs (2012) discussed in Section 2. Finally, as mentioned above, the financial crisis had its impact on the strength of the synchronisation effect exerted by FDI integration: the inclusion of the period after 2007 abates the coefficient our FDI intensity measure. Since year-specific effects are already taken into account, this may indicate a more profound change in the relevance of FDI linkages for synchronisation at the current edge. With respect to trade we do not find a significant impact for any subsample. Note, however, that the results based on relatively short samples should be interpreted with care since multicollinearity of trade and FDI integration could influence the results in these shorter samples as mentioned above.

\subsection{Sensitivity}

To test the sensitivity of our results, we estimate several variations of our basic specification.

Alternative Measures of FDI and Trade Linkages In a first step, we use alternative measures for FDI and trade intensity which take into account the asymmetry between countries. In case a country pair consists of countries which differ strongly with respect to their economic size, our trade and FDI integration measures may understate the importance of linkages for the small country. Therefore, we repeat our estimations employing a measure where bilateral trade and FDI linkages are scaled by the GDP of the smaller country as proposed by Otto et al. (2001):

$$
\begin{aligned}
T_{i j t}^{\text {alt. }} & =\max \left(\frac{E X_{i j t}+I M_{i j t}}{G D P_{i t}}, \frac{E X_{i j t}+I M_{i j t}}{G D P_{j t}}\right) \\
F D I_{i j t}^{\text {alt. }} & =\max \left(\frac{O u t_{i j t}+I n_{i j t}}{G D P_{i t}}, \frac{O u t_{i j t}+I n_{i j t}}{G D P_{j t}}\right) .
\end{aligned}
$$

Results, displayed in Table 4 column (1), are very similar to those in Table 1. The main difference lies in lower coefficients for FDI and trade integration, which is natural as the alternative measures are by definition bigger than the measures employed before. FDI linkages have a significant impact, even though significance drops to the $10 \%$ level. The coefficient of trade remains insignificant for the alternative measure.

Alternative Measures of Synchronisation Furthermore, we conduct estimations with alternative synchronisation measures. First, we use our synchronisation measure based on the business cycle computed as HP-filtered output instead of year-on-year growth rates of output. We test this measure as it is the most common measure of the output gap in literature. However, the HP filter implies that this alternative synchronisation measure is 
Table 4: Business Cycle Synchronisation: Sensitivity with Alternative Measures

\begin{tabular}{llllll}
\hline \hline & $(1)$ & $(2)$ & $(3)$ & $(4)$ & $(5)$ \\
$\begin{array}{l}\text { Sync. measure } \\
\text { based on }\end{array}$ & $\Delta$ GDP & $\Delta$ GDP & $\begin{array}{l}\text { HP-filtered } \\
\text { GDP }\end{array}$ & $\begin{array}{l}\text { Residual } \\
\Delta \text { GDP }\end{array}$ & $\begin{array}{l}\text { Relative } \\
\Delta \text { GDP }\end{array}$ \\
\hline FDI Alternative & 0.035 & & & & \\
FDI & $(0.018)^{*}$ & & & & \\
& & 0.249 & 0.139 & 0.194 & 12.936 \\
Trade Alternative & -0.029 & $(0.124)^{* *}$ & $(0.113)$ & $(0.136)$ & $(6.248)^{* *}$ \\
& $(0.025)$ & & & & \\
Trade & & -0.157 & 0.198 & -0.012 & -9.744 \\
Sectoral Differences & -0.041 & -0.039 & -0.049 & -0.032 & -1.456 \\
& $(0.008)^{* * *}$ & $(0.009)^{* * *}$ & $(0.008)^{* * *}$ & $(0.009)^{* * *}$ & $(0.436)^{* * *}$ \\
Monetary Policy & -0.099 & -0.097 & 0.017 & -0.147 & -1.820 \\
& $(0.022)^{* * *}$ & $(0.024)^{* * *}$ & $(0.022)$ & $(0.025)^{* * *}$ & $(1.039)^{*}$ \\
Fiscal Policy & 0.061 & 0.064 & 0.042 & 0.056 & 3.053 \\
& $(0.012)^{* * *}$ & $(0.012)^{* * *}$ & $(0.011)^{* * *}$ & $(0.013)^{* * *}$ & $(0.531)^{* * *}$ \\
Year Dummies & Yes & Yes & Yes & Yes & Yes \\
\hline$N$ & 1,793 & 1,793 & 1,793 & 1,793 & 1,793 \\
Hansen's J Test & & & & & \\
$\chi^{2}$ (d.f.) & $28.21(25)$ & $19.98(25)$ & $73.88(25)$ & $32.15(25)$ & $19.6(25)$ \\
p-value & 0.298 & 0.748 & 0.000 & 0.154 & 0.768 \\
\hline \hline
\end{tabular}

Notes: Standard errors in parentheses; ${ }^{* * *} \mathrm{p}<0.01,{ }^{* *} \mathrm{p}<0.05,{ }^{*} \mathrm{p}<0.1$.

smoother and exhibits a high degree of autocorrelation which may be problematic in a static panel approach. Second, we adopt a measure proposed by Morgan et al. (2004), which is computed in two steps: first, we recover the residuals from of a regression of real GDP growth on country-pair and year specific fixed effects:

$$
\Delta Y_{i t}=\mu_{i}+\lambda_{t}+\varepsilon_{i t}
$$

Simply speaking, this residual GDP growth captures for a given year a country's deviation from its own long-run GDP growth and from the cross-section average growth rate in that specific year. The alternative synchronisation measure is then constructed in a similar fashion as the basic measure by taking the negative absolute difference between residual GDP growth, 
i.e.,

$$
\rho_{i j t}^{\text {resid. }}=-\left|\varepsilon_{i t}-\varepsilon_{j t}\right|
$$

In contrast to our basic measure, this proxy is corrected for changes in the amplitude of fluctuations. Finally, we employ a measure proposed by Mink et al. (2007), which scales our original measure by the size of the average GDP growth rate in the sample and can be expressed as follows:

$$
\rho_{i j t}^{\text {relative }}=-\frac{\left|\Delta Y_{i t}-\Delta Y_{j t}\right|}{\frac{1}{n} \sum_{i=1}^{n}\left|\Delta Y_{i t}\right|} .
$$

In Table 4 we compare the estimated coefficients for these different measurement concepts with column (2) which repeats the result for our standard synchronisation measure. We find that for the latter measure results barely change in qualitative terms (column 5). Quantitatively, the coefficients are all much higher as the relative comovement measure has a much bigger value range (see descriptives in Table 5 in Appendix A). Using the synchronisation measure based on residual GDP growth, FDI is insignificant in the parsimonious specification but significant for several other instrumentations (not shown), whereas the remaining results persist (see column 4). When the HP-filtered measure is used in column (3), in addition to FDI, monetary policy looses its significance. But the instrumentation seems problematic when the dependent variable is based on HP-filtered GDP. There is no sign of weak instruments, but Hansen's J Test rejects the exogeneity of our parsimonious instrument set as well as of all alternative instrumentation attempts. Additionally, autocorrelation coefficients for the residuals strongly exceed those of our original measure of comovement.

Alternative Error Structure In our basic specification, contemporaneous correlation of the errors across panel individuals arising, e.g. by common shocks hitting the country pairs, are modelled by common time effects in the error term. To check the robustness of the reported results with respect to this choice, we follow an alternative approach proposed by Pesaran (2006) and include cross-sectional averages of the endogenous variables instead of year dummies in the estimation equations. The cross-sectional averages provide a solution to soak up cross-sectional correlation. The idea of this approach is to model the residuals of the panel equation as being composed of two orthogonal components. The first component comprises common factors that soak up the cross-sectional comovement in the data whereas the second component captures mainly idiosyncratic variable-specific movements. Following Pesaran (2006), we estimate the common factors consistently by cross-sectional averages of the country-specific variables (synchronisation, FDI, trade and sectoral differences) and their lagged values. In general, results are qualitatively very similar to those reported in 
Table 1 with year dummies, the only exception being the parsimonious specification with a negative trade coefficient which is significant at the $10 \%$ level (see Appendix B Table 7). But Hansen's J test rejects the validity of instruments for this specification pointing to inconsistent estimates. Quantitative changes occurred in the FDI coefficient which is about $20 \%$ higher in all specification when cross-sectional averages are included.

Estimation in Log-like Transformation We estimate our model not only in levels but also in a log-like transformation following Levy Yeyati et al. (2007) which for a variable $x$ can be written as ${ }^{19}$

$$
\operatorname{loglike}(x)=\operatorname{sign}(x) * \ln (1+\operatorname{abs}(x)) .
$$

We test this specification as many studies refer to models in logs, even though Kose and Yi (2006) make a strong point for an estimation in levels. Results produced by estimating the transformed system do not differ significantly from the ones of the basic specification and are not reported.

\section{Conclusion}

We readdressed the determinants of business cycle synchronisation in this paper to test, on the one hand, whether FDI promoting policies may have consequences for the business cycle comovement between countries, and on the other hand, whether more plausible identification strategies change previous results. Understanding the determinants of synchronisation is of great political relevance, since a considerable degree of cyclical comovement is important for the efficiency of a common monetary policy in a currency union. The importance of developing policies that enhance synchronisation is particularly evident in the light of the past years, when the heterogeneity in economic development between the countries in the eurozone increased, forcing the ECB to use country-targeted policy measures in addition to the common interest rate. Since these measures are highly disputed by experts and come at a risk, the ECB plans to abandon the non-standard measures once its member countries exhibit a stable and more similar economic development. Our results suggest that linkages through foreign direct investment contribute in most cases positively to the synchronisation between country pairs. This implies that policies to attract more FDI from abroad go, in general, hand in hand with an increased similarity of business cycles with these international partners. In the specific case of bilateral synchronisation between EMU members, we do not identify a positive significant effect but also no negative one. Thus, our results suggest

\footnotetext{
${ }^{19}$ This more complicated transformation is necessary, since FDI positions and in consequence our measure for bilateral FDI intensity can be negative and are therefore not compatible with a simple logarithmic transformation.
} 
no conflict of goals between policies to promote FDI and the necessary synchronisation of business cycles in the EMU. In contrast, the beneficial effects of trade integration for the similarity of business cycles are less robust and thus less important for the transmission of idiosyncratic shocks between countries than previously thought. One explanation for this result is, that trade moves together with business cycle synchronisation because of common shocks. Finally, we find that larger differences in the sector structure between two economies result in a bigger gap between their business cycles.

\section{References}

Aizenman, J. and I. Noy (2006). FDI and trade - two-way linkages? Quarterly Review of Economics and Finance 46(3), 317-337.

Alesina, A., R. J. Barro, and S. Tenreyro (2003). Optimal currency areas. In NBER Macroeconomics Annual 2002, Volume 17, pp. 301-356. MIT Press.

Alfaro, L. and M. X. Chen (2012). Surviving the global financial crisis: Foreign ownership and establishment performance. American Economic Journal: Economic Policy 4(3), $30-55$.

Backus, D. K., P. J. Kehoe, and F. E. Kydland (1992). International business cycles. Journal of Political Economy 100(4), 745-775.

Baier, S. L. and J. H. Bergstrand (2007). Do free trade agreements actually increase members' international trade? Journal of International Economics 71(1), 72-95.

Baltagi, B. H. (1981). Simultaneous equations with error components. Journal of Econometrics 17(2), 189-200.

Baltagi, B. H. (2008). Econometric Analysis of Panel Data. Chichester, UK: John Wiley \& Sons.

Baxter, M. and M. A. Kouparitsas (2005). Determinants of business cycle comovement: a robust analysis. Journal of Monetary Economics 52(1), 113-157.

Böwer, U. and C. Guillemineau (2006, February). Determinants of business cycle synchronisation across euro area countries. ECB Working Paper Series 587, ECB.

Budd, J. W., J. Konings, and M. J. Slaughter (2005). Wages and international rent sharing in multinational firms. Review of Economics and Statistics 87(1), 73-84. 
Burstein, A., C. Kurz, and L. Tesar (2008). Trade, production sharing, and the international transmission of business cycles. Journal of Monetary Economics 55(4), 775-795.

Cameron and Trivedi (2005). MICROECONOMETRICS: Methods and Applications. Cambridge, UK: Cambridge University Press.

Cavallari, L. (2007). A macroeconomic model of entry with exporters and multinationals. B.E. Journal of Macroeconomics 7(1), Article 32.

Cavallari, L. (2008). Macroeconomic interdependence with trade and multinational activities. Review of International Economics 16(3), 537-558.

Cavallari, L. (2010). Exports and foreign direct investments in an endogenous-entry model with real and nominal uncertainty. Journal of Macroeconomics 32(1), 300-313.

Chinn, M. D. and H. Ito (2008). A new measure of financial openness. Journal of Comparative Policy Analysis 10(3), 309-322.

Clark, T. E. and E. Van Wincoop (2001). Borders and business cycles. Journal of International Economics 55(1), 59-85.

Darvas, Z., A. K. Rose, and G. Szapary (2007). Fiscal divergence and business cycle synchronization: Irresponsibility is idiosyncratic. In J. Frankel and C. Pissarides (Eds.), NBER International Seminar on Macroeconomics 2005, pp. 261-298. MIT Press.

Davis, J. S. (2014). Financial integration and international business cycle co-movement. Journal of Monetary Economics 64, 99-111.

Dées, S. and N. Zorell (2012). Business cycle synchronisation: Disentangling trade and financial linkages. Open Economies Review 23(4), 623-643.

Desai, M. A. and C. F. Foley (2006). The comovement of returns and investment within the multinational firm. In R. H. Clarida, J. Frankel, F. Giavazzi, and K. D. West (Eds.), NBER International Seminar on Macroeconomics 2004, pp. 197-240. MIT Press.

Desai, M. A., C. F. Foley, and K. J. Forbes (2008). Financial constraints and growth: Multinational and local firm responses to currency depreciations. Review of Financial Studies 21 (6), 2857-2888.

Desai, M. A., C. F. Foley, and J. R. J. Hines (2004). A multinational perspective on capital structure choice and internal capital markets. Journal of Finance 59(6), 2451-2487.

Devereux, M. B. and A. Sutherland (2011). Evaluating international financial integration under leverage constraints. European Economic Review 55(3), 427-442. 
Devereux, M. B. and J. Yetman (2010). Leverage constraints and the international transmission of shocks. Journal of Money, Credit and Banking 42(6), 71-105.

Egger, P. (2000). A note on the proper econometric specification of the gravity equation. Economics Letters 66(1), 25-31.

Enders, Z., R. Kollmann, and G. J. Müller (2011). Global banking and international business cycles. European Economic Review 55(3), 407-426.

Feenstra, R. C., R. E. Lipsey, H. Deng, A. C. Ma, and H. Mo (2005). World trade flows: 1962-2000. NBER Working Paper Series 11040, NBER.

Frankel and Rose (1998). The endogeneity of the optimum currency area criteria. Economic Journal 108(449), 1009-1025.

Giannone, L. and Reichlin (2008, December). Business cycles in the euro area. NBER Working Paper Series 14529, NBER.

Heathcote, J. and F. Perri (2002). Financial autarky and international business cycles. Journal of Monetary Economics 49(3), 601-627.

Helpman, E., M. J. Melitz, and S. R. Yeaple (2004). Export versus FDI with heterogeneous firms. American Economic Review 94(1), 300-316.

Hovakimian, G. (2011). Financial constraints and investment efficiency: Internal capital allocation across the business cycle. Journal of Financial Intermediation 20(2), 264-283.

Hsu, C.-C., J.-Y. Wu, and R. Yau (2011). Foreign direct investment and business cycle co-movements: The panel data evidence. Journal of Macroeconomics 33(4), 770-783.

Ilzkovitz, F., A. Dierx, V. Kovacs, and N. Sousa (2007, January). Steps towards a deeper economic integration: the internal market in the 21st century. European Economy Economic Papers 271, Directorate General Economic and Monetary Affairs (DG ECFIN), European Commission.

Imbs, J. (2004). Trade, finance, specialization, and synchronization. Review of Economics and Statistics 86(3), 723-734.

Imbs, J. (2006). The real effects of financial integration. Journal of International Economics 68(2), 296-324.

Imbs, J. and R. Wacziarg (2003, March). Stages of diversification. American Economic Review 93(1), 63-86. 
Inklaar, R., R. Jong-A-Pin, and J. De Haan (2008). Trade and business cycle synchronization in OECD countries - a re-examination. European Economic Review 52(4), 646-666.

Jansen, W. J. and A. C. J. Stokman (2006). International rent sharing and domestic labour markets: a macroeconomic analysis. Review of World Economics 142(4), 792-813.

Jansen, W. J. and A. C. J. Stokman (2011). International business cycle comovement: Trade and foreign direct investment. Working Paper Series 319, De Nederlandsche Bank.

Kalemli-Ozcan, S., E. Papaioannou, and J.-L. Peydró (2013). Financial regulation, financial globalization, and the synchronization of economic activity. Journal of Finance 68(3), $1179-1228$.

Kappler, M. (2011). Business cycle co-movement and trade intensity in the euro area: is there a dynamic link? Journal of Economics and Statistics (Jahrbücher für Nationalökonomie \& Statistik) 231(2), 247-265.

Karadimitropoulou, A. and M. León-Ledesma (2013). World, country, and sector factors in international business cycles. Journal of Economic Dynamics and Control 37(12), 29132927.

Keil, J. and A. Sachs (2012). Determinants of business cycle synchronization. In M. Kappler and A. Sachs (Eds.), Business Cycle Synchronisation and Economic Integration: New Evidence from the EU, Chapter 4, pp. 95-148. ZEW Economic Studies.

Kleinert, J., J. Martin, and F. Toubal (2012). The few leading the many: Foreign affiliates and business cycle comovement. Globalization and Monetary Policy Institute Working Paper 116, Federal Reserve Bank of Dallas.

Kose, A. M., C. Otrok, and C. H. Whiteman (2008). Understanding the evolution of world business cycles. Journal of international Economics 75(1), 110-130.

Kose, M. A., C. Otrok, and E. Prasad (2012). Global business cycles: Convergence or decoupling? International Economic Review 53(2), 511-538.

Kose, M. A., E. S. Prasad, and M. E. Terrones (2003). How does globalization affect the synchronization of business cycles? American Economic Review 93(2), 57-62.

Kose, M. A. and K.-M. Yi (2006). Can the standard international business cycle model explain the relation between trade and comovement? Journal of International Economics 68(2), 267-295. 
La Porta, R., F. L. Siliances, A. Schleifer, and R. W. Vishny (1998). Law and finance. Journal of Political Economy 106, 1113-1155.

Levy Yeyati, E., U. Panizza, and E. Stein (2007). The cyclical nature of north-south FDI flows. Journal of International Money and Finance 26(1), 104-130.

Mink, M., J. Jacobs, and J. De Haan (2007). Measuring synchronicity and co-movement of business cycles with an application to the euro area. CESifo Working Papers 2112, CESifo.

Morgan, D. P., B. Rime, and P. E. Strahan (2004). Bank integration and state business cycles. Quarterly Journal of Economics 119(4), 1555-1584.

Olivero, M. P. (2010). Market power in banking, countercyclical margins and the international transmission of business cycles. Journal of International Economics 80(2), 292-301.

Otto, G., G. Voss, and L. Willard (2001). Understanding OECD output correlations. Research Discussion Paper 2001-05, Reserve Bank of Australia.

Pesaran, M. H. (2006). Estimation and inference in large heterogeneous panels with a multifactor error structure. Econometrica 74(4), 967-1012.

Russ, K. N. (2007). The endogeneity of the exchange rate as a determinant of FDI: A model of entry and multinational firms. Journal of International Economics 71(2), 344-372.

Schiavo, S. (2008). Financial integration, GDP correlation and the endogeneity of optimum currency areas. Economica 75 (297), 168-189.

Schindler, M. (2009). Measuring financial integration: A new data set. IMF Staff Papers $56(1), 222-238$.

Stevens, G. and R. Lipsey (1992). Interactions between domestic and foreign investment. Journal of International Money and Finance 11(1), 40-62.

Ueda, K. (2012). Banking globalization and international business cycles: Cross-border chained credit contracts and financial accelerators. Journal of International Economics 86(1), 1-16.

Yetman, J. (2011). Exporting recessions: International links and the business cycle. Economics Letters 110(1), 12-14. 


\section{A Measures and Data Sources}

Synchronisation: Negative absolute difference of real GDP growth, see equation (6). Source: OECD Economic Outlook.

HP-filtered synchronisation measure: Negative absolute difference of HP-filtered GDP. Source: OECD Economic Outlook.

Residual synchronisation measure: Negative absolute difference of real residual GDP growth after eliminating time and country-pair effects, see equations (13) and (14). Source: OECD Economic Outlook.

Relative synchronisation measure: Negative absolute difference of real GDP growth divided by average absolute GDP growth, see equation (15). Source: OECD Economic Outlook.

FDI integration: Sum of bilateral FDI inward and outward positions divided by the sum of nominal GDP, see equation (7). Source: OECD International Direct Investment Statistics; World Bank, World Development Indicators.

Alternative FDI integration: Sum of bilateral FDI inward and outward positions divided by the sum of total FDI positions, see equation (12). Source: OECD International Direct Investment Statistics.

Trade integration: Bilateral import and export divided by the sum of nominal GDP, see equation (8). Source: IMF, Direction of Trade Statistics; World Bank, World Development Indicators.

Alternative trade integration: Bilateral import and export divided by the sum of total trade, see equation (11). Source: IMF, Direction of Trade Statistics; World Bank, World Development Indicators.

Differences in the sector structure: Sum over negative absolute differences between value added shares for 41 sectors, see equation (9). Source: OECD STAN database.

Monetary policy: Absolute difference in short term interest rates (three month nominal interest rate, mainly interbank rates). Source: OECD Economic Outlook.

Fiscal policy: Absolute difference in government budget balance. Source: IMF, World Economic Outlook April 2012.

Return spreads between share price indices: Absolute difference in growth of share price index. Source: IMF, IFS.

Volume-based measure of capital openness: Bilateral sum of gross private capital flows ratio to GDP. Source: World Bank WDI.

Economic similarity: Indicator based on nominal GDP following Egger (2000), see equation (10). Source: World Bank, World Development Indicators.

Overall economic development: Bilateral sum of GDP per capita (in PPP). Source: World Bank, International Comparison Program database. 
Differences in economic development: Absolute differences in GDP per capita (in PPP). Source: World Bank, International Comparison Program database.

De jure economic integration: Ranking of bilateral degree of economic integration. Source: Baier and Bergstrand (2007), Database on Economic Integration Agreements.

De jure capital openness: Bilateral sum of an index measuring share holder rights. Source: La Porta et al. (1998).

Distance between the main economic centers: Mean of (by population) weighted distances between biggest cities/areas. Source: CEPII, GRAVITY dataset, http://www.cepii.fr/CEPII/en/bdd_modele/bdd.asp.

Common border: Dummy variables with value 1 if countries have a common border and 0 otherwise. Source: CEPII, GRAVITY dataset, http://www.cepii.fr/CEPII/en/bdd_modele/bdd.asp.

Table 5: Descriptive Statistics

\begin{tabular}{l|rrrrr}
\hline \hline Variable & Obs & Mean & Std. Dev. & Min & Max \\
\hline Synchronisation & 3360 & -0.017 & 0.017 & -0.169 & 0.000 \\
HP-filtered Sync. & 3360 & -0.019 & 0.017 & -0.107 & 0.000 \\
Residual Sync. & 3360 & -0.017 & 0.017 & -0.177 & 0.000 \\
Relative Sync. & 3360 & -0.696 & 0.691 & -4.496 & 0.000 \\
FDI & 2744 & 0.006 & 0.012 & -0.001 & 0.119 \\
FDI Alternative & 2744 & 0.034 & 0.064 & -0.002 & 0.540 \\
Trade & 3360 & 0.006 & 0.008 & 0.000 & 0.039 \\
Trade Alternative & 3360 & 0.033 & 0.048 & 0.001 & 0.549 \\
Sectoral Differences & 2685 & 0.329 & 0.106 & 0.107 & 0.823 \\
Monetary Policy & 3360 & 0.030 & 0.033 & 0.000 & 0.189 \\
Fiscal Policy & 2454 & 0.047 & 0.044 & 0.000 & 0.285 \\
Return Spread & 3022 & 0.173 & 0.202 & 0.000 & 2.115 \\
Capital Openness & 3345 & -0.001 & 0.006 & -0.036 & 0.030 \\
Economic Similarity & 3360 & 0.298 & 0.155 & 0.021 & 0.500 \\
Economic Development & 3360 & 5.390 & 1.104 & 2.760 & 9.289 \\
Development Differences & 3360 & 0.583 & 0.474 & 0.000 & 2.71 \\
Economic Integration Agreements & 2880 & 2.833 & 2.205 & 0.000 & 6.000 \\
De Jure Capital Openness & 3360 & 6.125 & 1.773 & 2.000 & 10.00 \\
Distance & 3360 & 3695 & 3203 & 379.2 & 11035 \\
Common Border & 3360 & 0.117 & 0.321 & 0.000 & 1.000 \\
\hline \hline
\end{tabular}




\section{B Additional Tables and Figures}

Table 6: Business Cycle Synchronisation: 2SLS Cross-Section Basic Specification (Including Time-Invariant Instruments)

\begin{tabular}{llll}
\hline \hline & $(1)$ & $(2)$ & $(3)$ \\
Period & $1982-2009$ & $1982-1998$ & $1999-2009$ \\
\hline FDI & 0.118 & -0.268 & 0.312 \\
& $(0.164)$ & $(0.398)$ & $(0.175)^{*}$ \\
Trade & 0.058 & 0.485 & -0.400 \\
& $(0.208)$ & $(0.251)^{*}$ & $(0.283)$ \\
Sectoral Differences & -0.000 & 0.004 & -0.026 \\
& $(0.016)$ & $(0.014)$ & $(0.014)^{*}$ \\
Monetary Policy & -0.120 & -0.074 & -0.135 \\
& $(0.037)^{* * * *}$ & $(0.022)^{* * *}$ & $(0.058)^{* *}$ \\
Fiscal Policy & -0.029 & -0.083 & 0.054 \\
& $(0.034)$ & $(0.036)^{* *}$ & $(0.025)^{* *}$ \\
\hline$N$ & 120 & 102 & 120 \\
Hansen's J Test & & & \\
$\chi^{2}$ (d.f.) & $7.47(3)$ & $1.62(3)$ & $2.49(3)$ \\
p-value & .058 & .655 & .477 \\
\hline \hline
\end{tabular}

Notes: Standard errors in parentheses; ${ }^{* * *} \mathrm{p}<0.01,{ }^{* *} \mathrm{p}<0.05,{ }^{*} \mathrm{p}<0.1$. 
Table 7: Business Cycle Synchronisation: EC2SLS with Cross-Section Averages instead of Year Dummies

\begin{tabular}{llllll}
\hline \hline & $(1)$ & $(2)$ & $(3)$ & $(4)$ & $(5)$ \\
Instrumentation & Pars. & Ec. Diff. & Return Spread & EIA & L.FDI \\
Period & $1983-2009$ & $1983-2009$ & $1983-2009$ & $1988-2005$ & $1983-2009$ \\
\hline FDI & 0.337 & 0.350 & 0.368 & 0.541 & -0.018 \\
& $(0.095)^{* * *}$ & $(0.122)^{* * *}$ & $(0.122)^{* * *}$ & $(0.179)^{* * *}$ & $(0.063)$ \\
Trade & -0.248 & -0.284 & -0.276 & -0.255 & 0.080 \\
& $(0.145)^{*}$ & $(0.186)$ & $(0.175)$ & $(0.240)$ & $(0.190)$ \\
Sectoral Differences & -0.039 & -0.039 & -0.039 & -0.031 & -0.039 \\
& $(0.007)^{* * *}$ & $(0.008)^{* * *}$ & $(0.008)^{* * *}$ & $(0.010)^{* * *}$ & $(0.011)^{* * *}$ \\
Monetary Policy & -0.092 & -0.086 & -0.084 & -0.087 & -0.055 \\
& $(0.022)^{* * *}$ & $(0.023)^{* * *}$ & $(0.023)^{* * *}$ & $(0.026)^{* * *}$ & $(0.024)^{* *}$ \\
Fiscal Policy & 0.059 & 0.062 & 0.064 & 0.056 & 0.053 \\
& $(0.012)^{* * * *}$ & $(0.012)^{* * *}$ & $(0.012)^{* * *}$ & $(0.015)^{* * * *}$ & $(0.012)^{* * *}$ \\
Cross-Section Av. & Yes & Yes & Yes & Yes & Yes \\
\hline$N$ & 1,788 & 1,788 & 1,786 & 1,447 & 1,750 \\
Hansen's J Test & & & & & \\
$\chi^{2}$ (d.f.) & $31.58(13)$ & $21.15(15)$ & $25.98(15)$ & $25.1(15)$ & $16.9(15)$ \\
p-value & .003 & .132 & .038 & .049 & .325 \\
\hline \hline
\end{tabular}

Notes: Standard errors in parentheses; ${ }^{* * *} \mathrm{p}<0.01,{ }^{* *} \mathrm{p}<0.05,{ }^{*} \mathrm{p}<0.1$. 


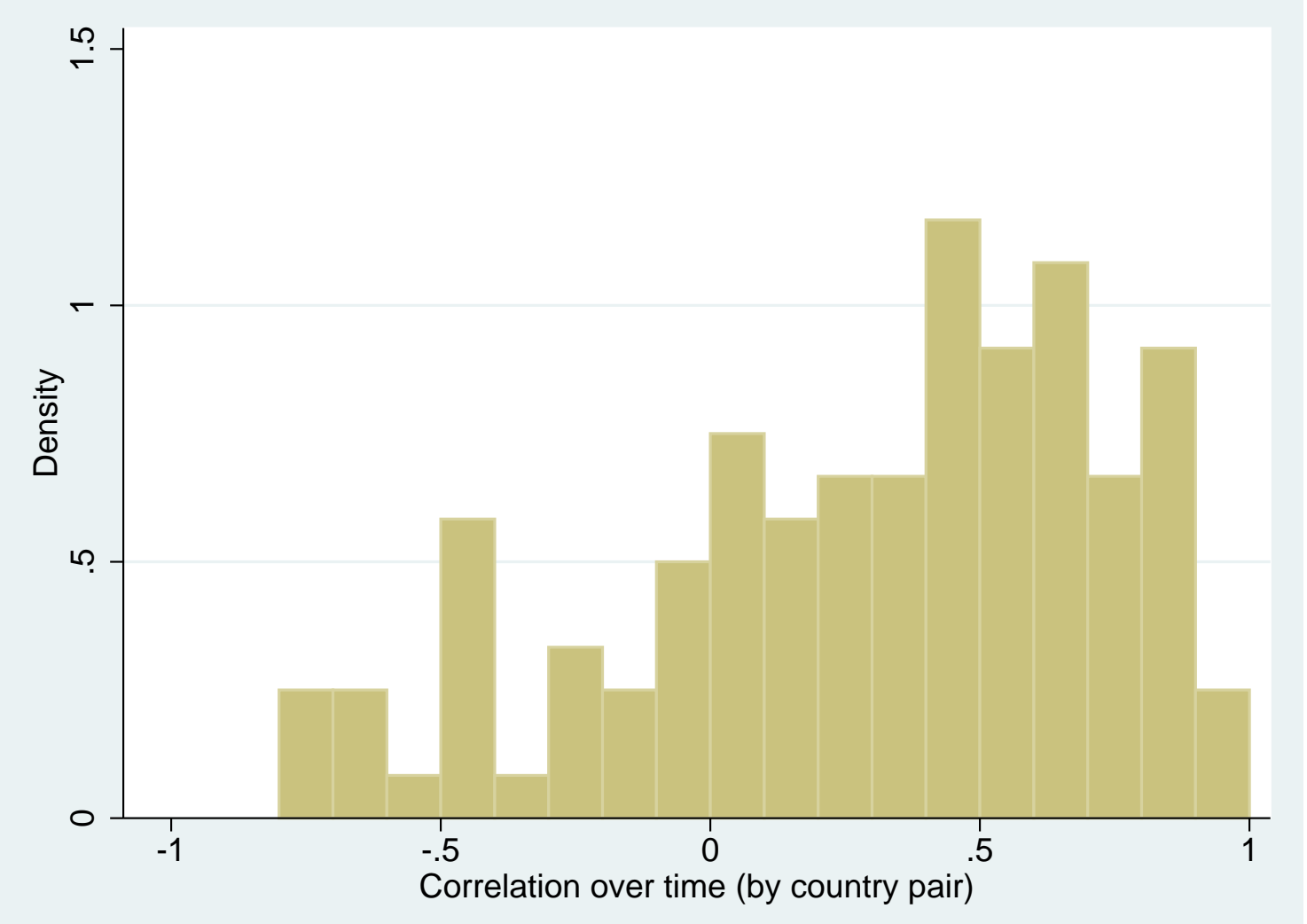

Figure 2: Distribution of "Within"-Correlation of Trade and FDI Integration 


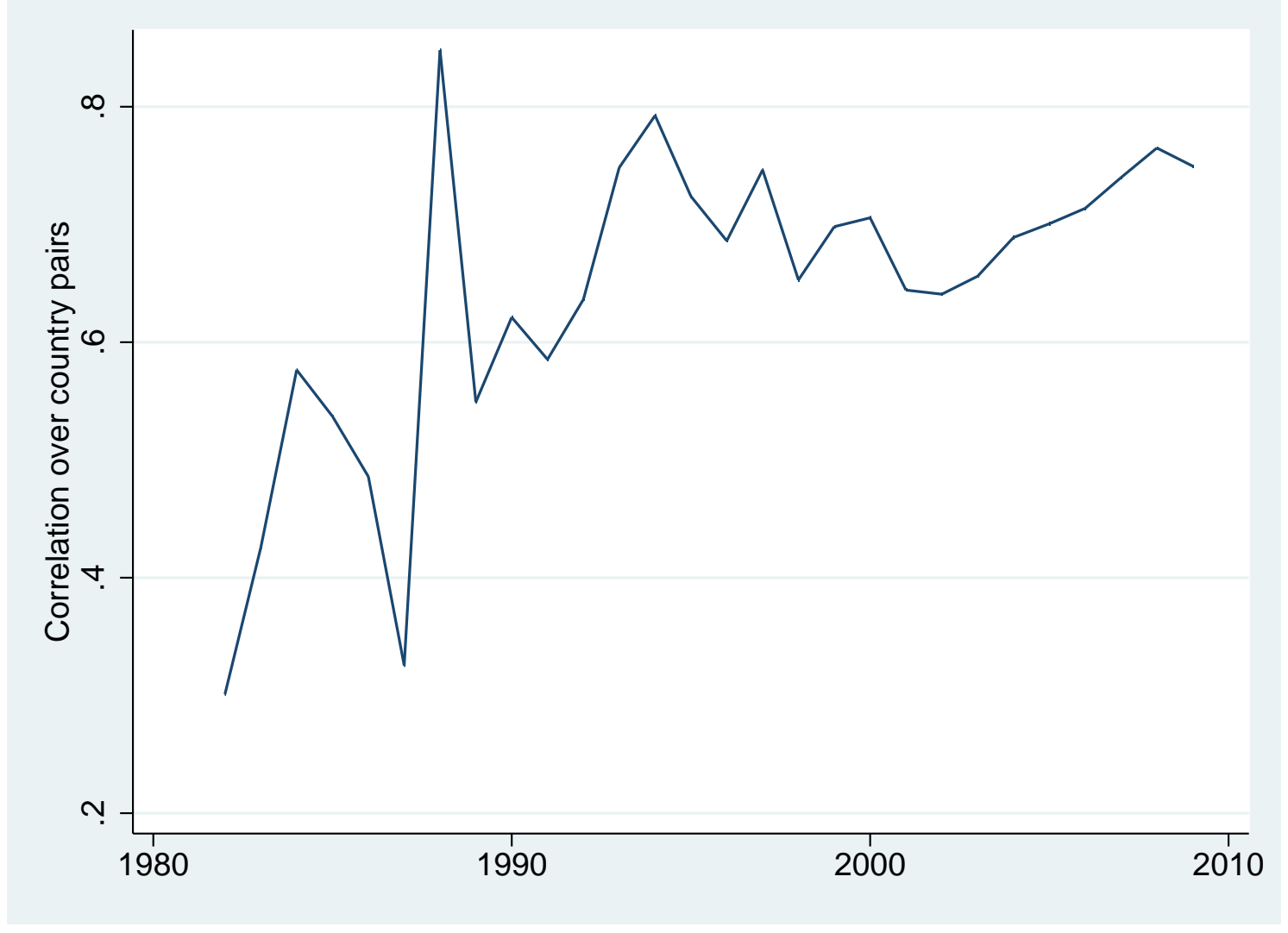

Figure 3: Evolution of "Between"-Correlation of Trade and FDI Integration 